\title{
Electrical Analysis of Red Dragon Fruit Stem (Hydrocereus polyrhizus) as a Source of Electrical Energy
}

\author{
Karlin Marta Putri ${ }^{1}$, Helendra ${ }^{1}$, Aidhia Rahmi ${ }^{1}$ \\ ${ }^{I}$ Department of Physics Education, STKIP PGRI Sumatera Barat \\ Gunung Pangilun, Padang City, Indonesia \\ *Email: alinmp589@gmail.com
}

\section{Article History}

Received: 21January 2021

Revised: 22 February 2021

Accepted: 29 June 2021

Published: 30 June 2021

\section{Key Words}

Red dragon fruit stem; Current; Voltage;

Power.

\begin{abstract}
This research aims to analyze electricity in the red dragon of fruit stem. The dragon fruit stem used are the red dragon fruit stem (Hydrocereus Polyrhizus). The type of research used is experimental research. The testing phase is the measurement of electricity from the pasta and red dragon fruit stalks using a variation of time and number of stem. The highest research results were found in 5 red dragon fruit stick pasta arranged in series, were (current $0.1 \mathrm{~mA}$; voltage $2.8 \mathrm{~V}$; power $0.28 \mathrm{~W}$; energy $504 \mathrm{~J}$ ). We found the highest research results in 15 red dragon fruit stick pasta arranged in series, namely (current $0.35 \mathrm{~mA}$; voltage $9.2 \mathrm{~V}$; power $3.22 \mathrm{~W}$ ). We found the highest research results in 15 red dragon fruit stick pasta arranged in parallel, namely (current $2 \mathrm{~mA}$; voltage $1 \mathrm{~V}$; power $1.92 \mathrm{~W}$ ). The conclusion of this research is that the longer the time variation, the lower the current, voltage, power, and energy, while the more the variation in the number of stem, the greater the current, voltage, power, and energy produced.
\end{abstract}

\section{INTRODUCTION}

The need for energy sources is currently experiencing a fairly rapid increase. Especially the source of electrical energy is an important need for the community to support activities such as business, education, and other activities that require electrical energy. These needs will continue to increase with the times and technology. Problems with electricity sources often occur, especially in rural communities that have not received electricity evenly. This disrupts the activities of rural communities. Besides population factors, community activities also affect the need for electrical energy sources. The higher economic activity causes the need for electrical energy to increase rapidly (Rajagukguk, Agus, Sofyan, 2015).

One effort to meet electricity needs is by researching alternative energy sources in natural resources. We source alternative energy from waste materials that have never been used. So that alternative energy becomes an energy source that is environmentally friendly and can be renewed. Several methods that can produce a source of electrical energy are electrochemical reactions. The reaction occurs through two electrodes that have a potential difference and are connected to an electrolyte solution. Electrolyte solution flowing by two electrodes, the electrolyte solution will produce moving ions. This reaction causes sending electrons from the anode to the cathode which produce current and voltage. The electrical energy produced depends on the type of electrolyte solution given. Currently, the author uses fruit waste as a source of electrolytes that produces alternative electrical energy (Hendri et al., 2015).

Previous research using plants such as shape of age from fruit and vegetable by Riva' Atul (Imama. A. R., 2015) Red dragon fruit stem. 
Red dragon fruit (Hylocereus polyrhizus) Native to Central America, South America, and Mexico, red dragon fruit stem have electrical energy because they are of the same genus as cacti (Tempo.com, 2013). The stem of the red dragon have a triangular shape and grow climbing on a wooden medium. The stem of this plant have short spines and are not sharp. They originally only knew this plant as an ornamental plant that has high economic value. This type of plant has red fruit skin with purplish-red flesh (Panjuantiningrum, 2009)

One type of plant that has a high antioxidant content is red dragon fruit. Some examples of antioxidant compounds are tannins, flavonoids, alkaloids, steroids, saponins, and vitamin C. Vitamin C compounds have specific compounds with the type of bond consisting of $\mathrm{O}-\mathrm{H}, \mathrm{CH} 2, \mathrm{CH}, \mathrm{C}-\mathrm{O}, \mathrm{C}=\mathrm{O}$, and $\mathrm{C}=\mathrm{C}$. $\mathrm{We}$ found these antioxidant compounds in plant parts such as flesh, roots, bark, stem, and leaves (Ilham Noor, Muhammad, Yufita, Zulfalina, 2016).

The triangular-shaped dragon fruit stem have a bluish-green color that grows lengthwise. On the dragon fruit stem, some shoots function in the assimilation process. The shoots on the stem are overgrown with hard spines that are short and not too prominent. The thorns are at the edges of the trunk and branches (Kristanto, 2003). The stem of the red dragon fruit Hylocereus polyrhizuz contain mucus and is coated with wax when it reaches the adult stage. Funnel-shaped flowers and inside there are pistils and stamens. According to (Idawati, 2013), Hylocereus polyrhizuz is a hermaphrodite plant that has multiple sexes.

The potential of natural resources is one of the right steps as an alternative source of electricity. As a country with a tropical climate, Indonesia is one country that have natural resources both from mining and agriculture. In years 2000, the government of West Sumatra, especially the district of Padang Pariaman, bred dragon fruit (Haluan harian.com., 2018).

The utilization of dragon fruit stem is still very minimal, although the amount of waste from dragon fruit stem is abundant and can pollute the environment. The content found in the stem of dragon fruit is high in fiber. However, the high water content in the stem of dragon fruit causes a brief shelf life. To produce fruit, the stem of the dragon fruit must be cut again. The waste of dragon fruit stem found in dragon fruit orchards reaches tons. However, the use of dragon fruit stem is still minimal, even though it has many benefits that are not inferior to the fruit.

This research was conducted to determine the electrical analysis of red dragon fruit stem Hydrocereus Polyrhizus as a source of electrical energy using a series of electrode cells, the electrode consists of 2 parts, namely the cathode such as copper $(\mathrm{Cu})$ while the anode such as zinc $(\mathrm{Zn})$. The ionic solution flows through a pair of electrodes, the positive electrode will attract negative ions and the negative electrode will attract positive ions (Oren, 2008).

\section{METHOD}

We conducted the research at the Basic Physics Laboratory of the Physics Education Study Program, STKIP PGRI, West Sumatra. They took the stem of the red dragon fruit used in this study from Bukittinggi.

Research Stages

Stage I: Find and collect red dragon fruit stem waste.

Stage II: Pasta or sticks of red dragon fruit as a source of electrolytes.

1) Red dragon fruit stem are cut into $10 \mathrm{~cm}$ long.

2) The dragon fruit stick pasta is mashed.

3) Plug the zinc ( $\mathrm{Zn})$ electrode as the negative pole (-) and copper $(\mathrm{Cu})$ as the positive $(+)$ pole on the red dragon fruit pasta and stem.

4) Measure current and voltage.

Stage III: Arrange series and parallel circuits.

Figure 1 is an example of a series for variations in the number of stem sourced from red dragon fruit pasta/stem. Figure 2 is an example of a parallel circuit for variations in the number of stem sourced from red dragon fruit pasta/stem.

\section{RESULTS AND DISCUSSION}

We can see the test results in the graph. Figure 3 shows the relationship between current to time in series. Electric current is a continuous flow of electrons in a conductor because of the difference in the number of electrons in several locations with the number of electrons being 
unequal. According to (Dinata \& Sunanda, 2015) Electric current has units of Ampere. The current produced by the red dragon fruit stem pasta is greater than that of the red dragon fruit stem. However, the current produced decreases with increasing time. This is in line with research
(Irsan et al., 2015) shows that the less the acid content in a material, the less the current produced is because of the decrease in the number of ions in the electrolyte solution in the $\mathrm{rod} /$ pasta because it is used to turn on the lamp.

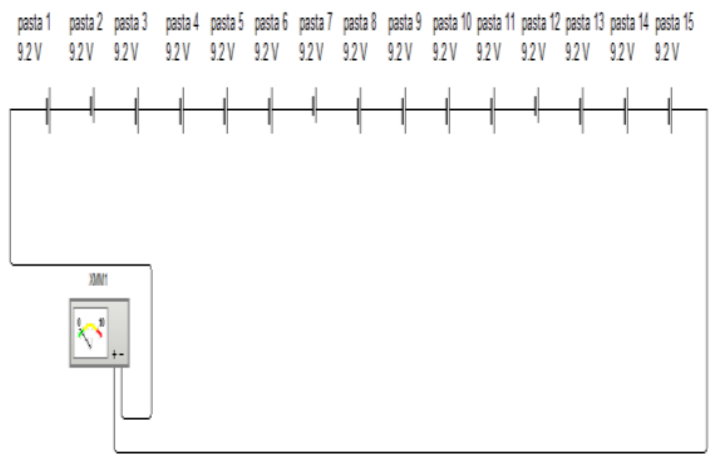

Figure 1. Example of a Series of Variations in the Number of Stem in Red Dragon Fruit Pasta/Stem.

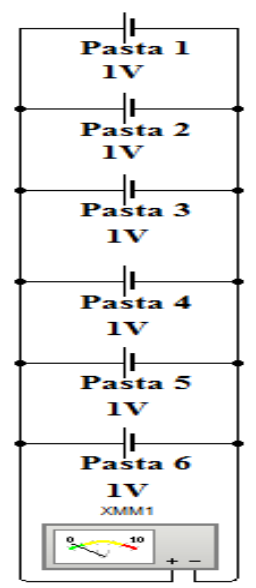

Figure 2. Example of a Parallel Circuit for Variations in the Number of Stem in Red Dragon Fruit Pasta/Stem

1. Graph of Current Relationship to Time Variation in Series

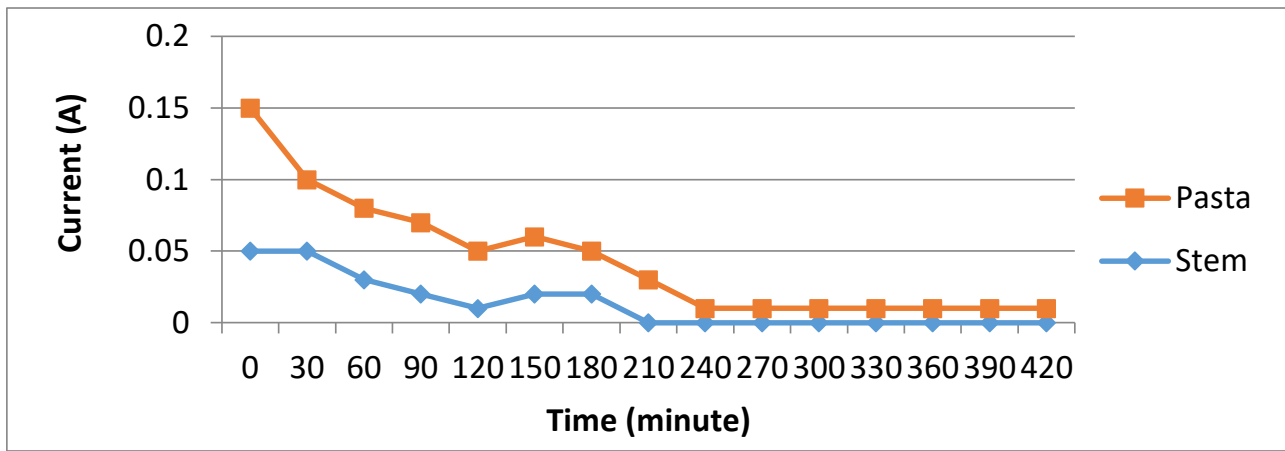

Figure 3. Graph of the Relationship Between Current and Time in Series on Pasta and Red Dragon Fruit Stem 
2. Graph of the Relationship of Voltage to Time Variations in Series

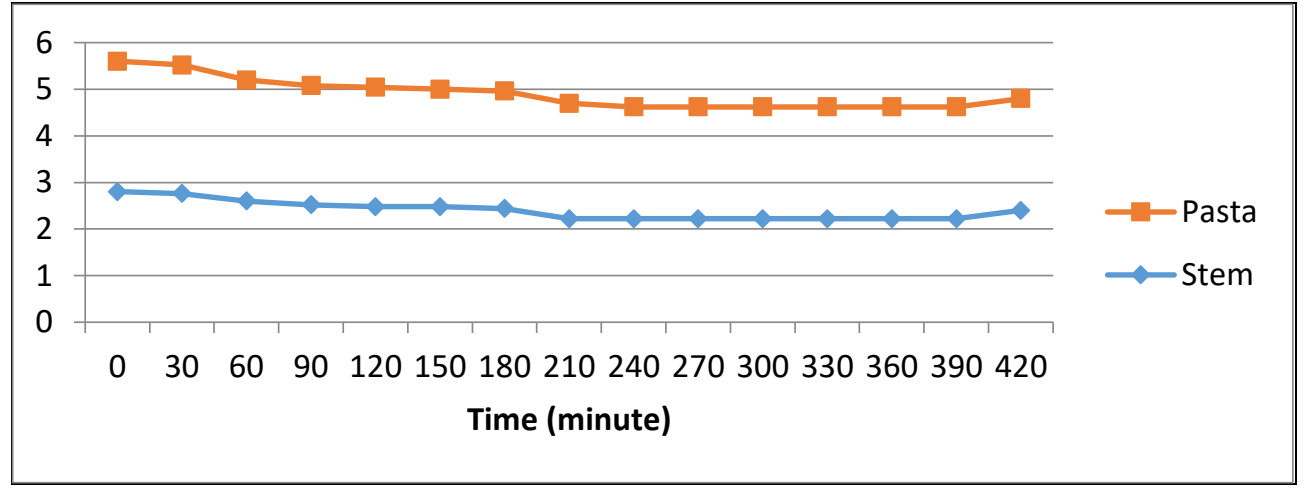

Figure 4. Graph of the Relationship Between Stress and Time on Pasta and Red Dragon Fruit Stem

3. Graph of Power Relationship to Time Variation in Series

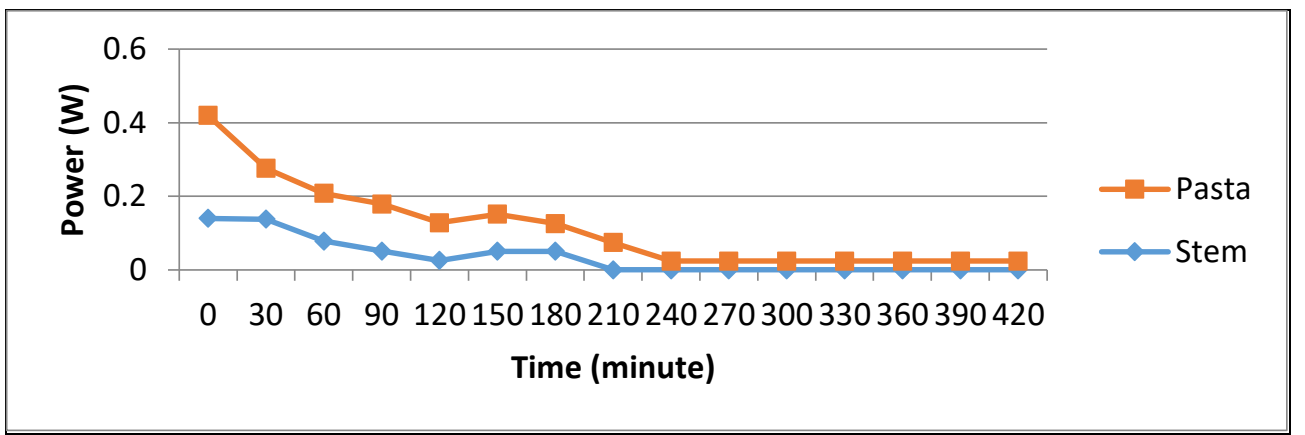

Figure 5. Graph of the Relationship of Power to Time in Series on Pasta and Red Dragon Fruit Stem

4. Graph of the Relationship of Energy to Time Variations in Series

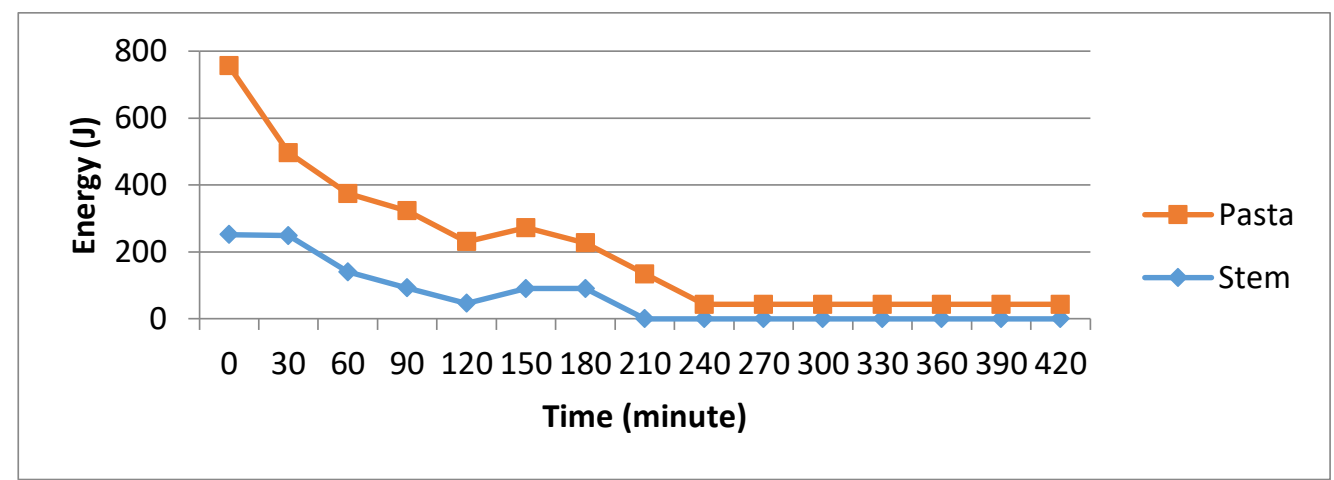

Figure 6. Graph of the Relationship Between Energy and Time in Series on Pasta and Red Dragon Fruit Stem. 
Figure 4 shows the stress-time relationship of the pasta and stem of the red dragon fruit. Voltage or potential difference (voltage) is the work done to move a charge. The relationship between the work done as energy used, so that we can simplify the definition into voltage, is energy per unit charge (Dinata \& Sunanda, 2015) in duration from 0 to 420 minutes. The tension produced by the red dragon fruit stem pasta is greater than that of the red dragon fruit stem. In line with research (Irsan et al., 2015) shows that the longer the red dragon fruit pasta/stem is tested using time variations, the resulting voltage will decrease. The electrolyte caused the resulting voltage drop during the test process used to experience ionization.

Figure 5 shows the power-to-time relationship of red dragon fruit pasta and stem for a duration of 0 to 420 minutes. We can see it in the power's graph relationship produced by each sample, namely the longer the variation in time, the power produced by each sample decreases. This is because power results from the formula $\mathrm{P}=\mathrm{V} \times \mathrm{I}$, meaning that if the voltage and current obtained are large, the power generated is also large, otherwise if the voltage and current obtained are small, the power generated is also small. We can see this from the LED light indicator that changes from dazzling to bright and then dim.

Figure 6 shows the relationship between energy and time of red dragon fruit pasta and stem for a duration of 0 to 420 minutes. We can see it in the energy's graph relationship produced by each sample, namely the longer the variation in time the energy produced by each sample decreases. This is because energy results from the formula $\mathrm{W}=\mathrm{P} \times \mathrm{t}$, meaning that if the power obtained is large, the energy produced is also large, otherwise if the power obtained is small, the energy produced is also small. We can see this from the LED light indicator, which changes from dazzling to bright and then dim (Ahmad Wahid, 2014)

Figure 7 shows the current relationship with variations in the number of stem sourced from pasta and red dragon fruit stem from 1 stem to 15 stem. The graph above shows that the current relationship to the variation in the number of stem connected in series originating from pasta and red dragon fruit stem is almost constant. This corresponds to (Rosman, 2019) if several DC voltage sources are arranged in series, then the total amount of current generated is the same.

5. Graph of the Relationship of Current to Variation in the Number of Stem in Series

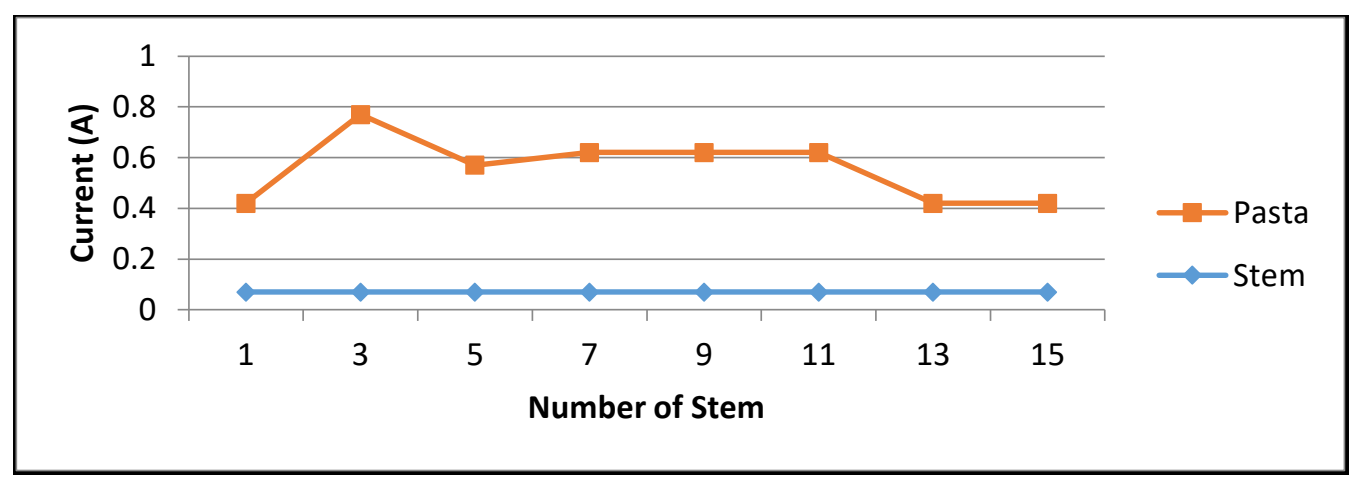

Figure 7. Graph of the Current Relationship to the Number of Stem Connected in Series on Pasta and Red Dragon Fruit Stem 
6. Graph of the Relationship of Voltage to Number of Stem in Series

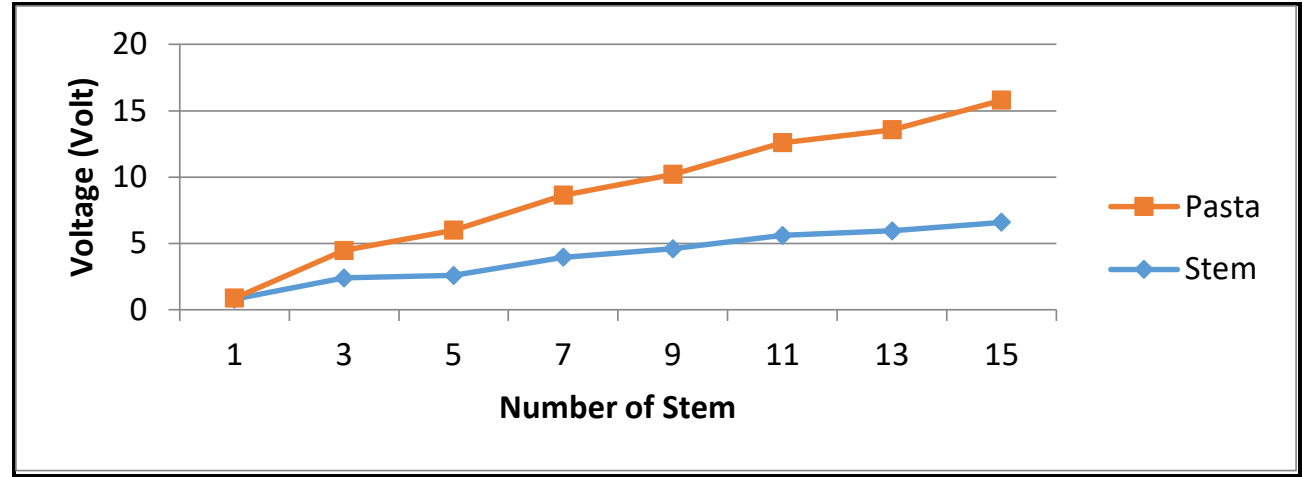

Figure 8. Graph of the Relationship of Stress to the Number of Stem Connected in Series on Pasta and Red Dragon Fruit Stem.

Figure 8 shows the relationship of stress to the number of stem connected in series from pasta and red dragon fruit stem. Variations in the number of stem used range from 1 to 15 stem. We can see it in the graph that the stress produced on the red dragon fruit stem pasta is greater than that of the red dragon fruit stem for each variation in the number of stem. This corresponds to a DC voltage source, the more the number of voltage sources, the greater the total voltage generated.

Figure 9 shows the power relationship to variations in the number of stem connected in series from pasta and red dragon fruit stem. We can see it in the power's graph relationship produced by each sample, namely the more variations in the number of bars, the more power produced by each sample increases. This is because power results from the formula $\mathrm{P}=\mathrm{V} x$ I, meaning that if the voltage and current obtained are large, the power generated is also large, otherwise if the voltage and current obtained are small, the power generated is also small.

Figure 10 shows the current relationship to variations in the number of stem arranged in parallel from pasta and red dragon fruit stem. The graph above shows that the current relationship to the number of stem arranged in parallel originating from pasta and red dragon fruit stem is increasing as more and more electrolyte sources are used. This corresponds to if we arrange several DC voltage sources in parallel, the total current generated is increasing.

7. Graph of Power Relationship to Number of Stem in Series

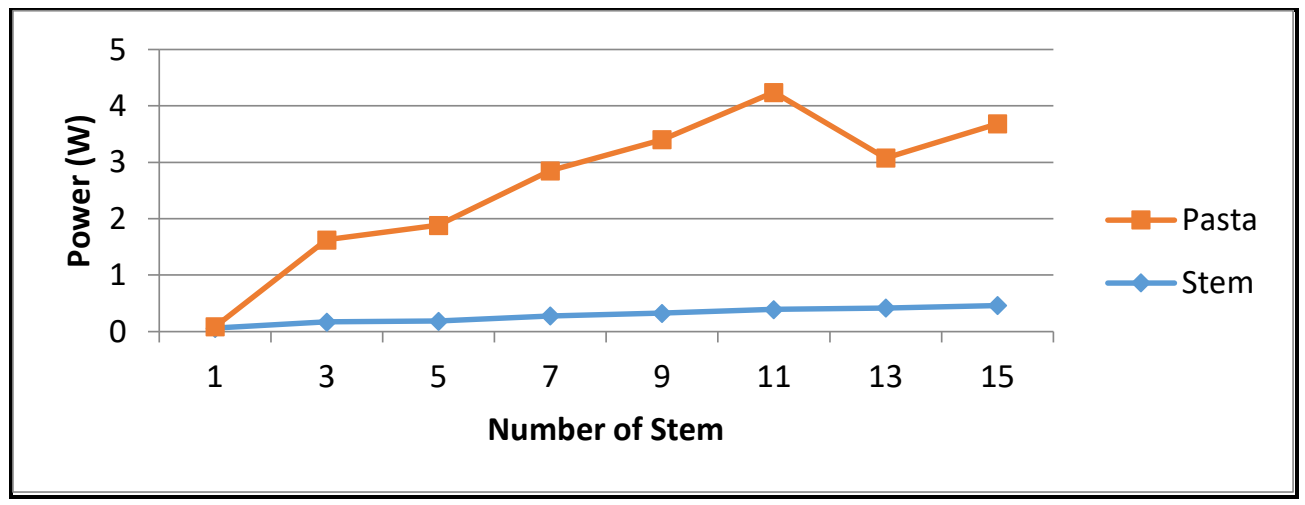

Figure 9. Graph of Power Relationship to Number of Stem in Series on Pasta and Red Dragon Fruit Stem 
8. Graph of Current Relationship to Number of Stem Arranged in Parallel

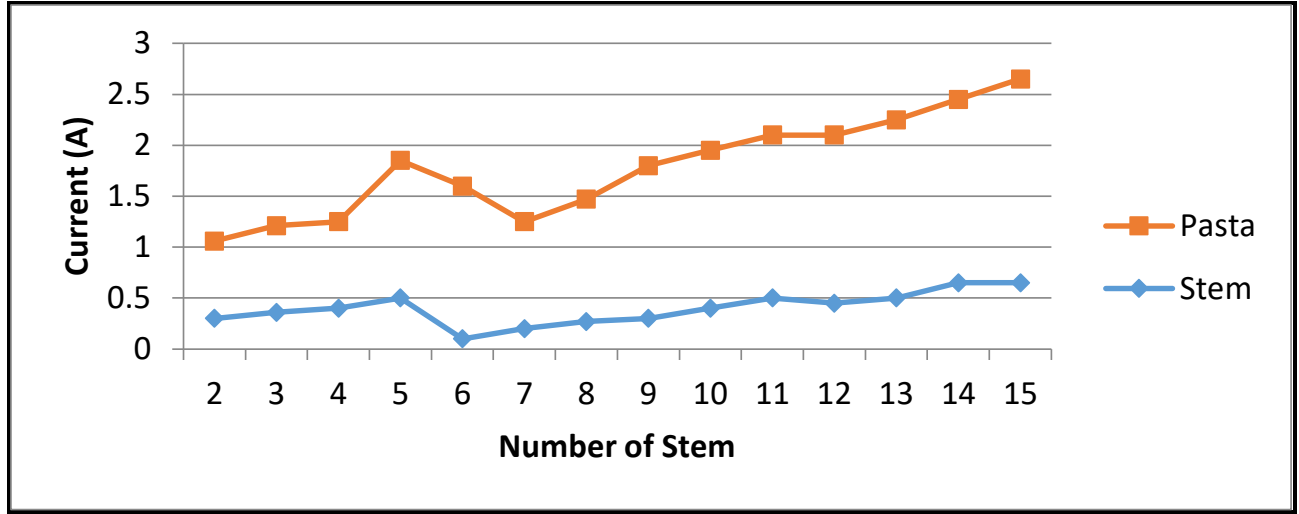

Figure 10. Graph of the Current Relationship with the Number of Stem Arranged in Parallel on Pasta and Red Dragon Fruit Stem.

9. Graph of the Relationship of Voltage to Number of Stem Arranged in Parallel

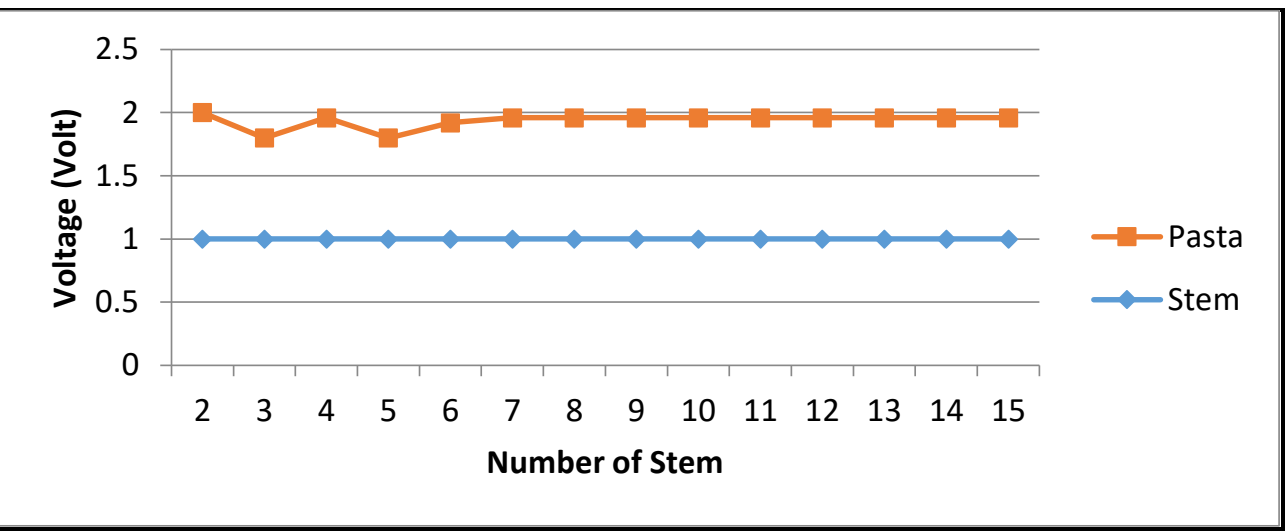

Figure 11. Graph of the Relationship of Voltage to Number of Stem Arranged in Parallel on Pasta and Red Dragon Fruit Stem.

10. Graph of Power Relationship to Number of Stem Arranged Parallel

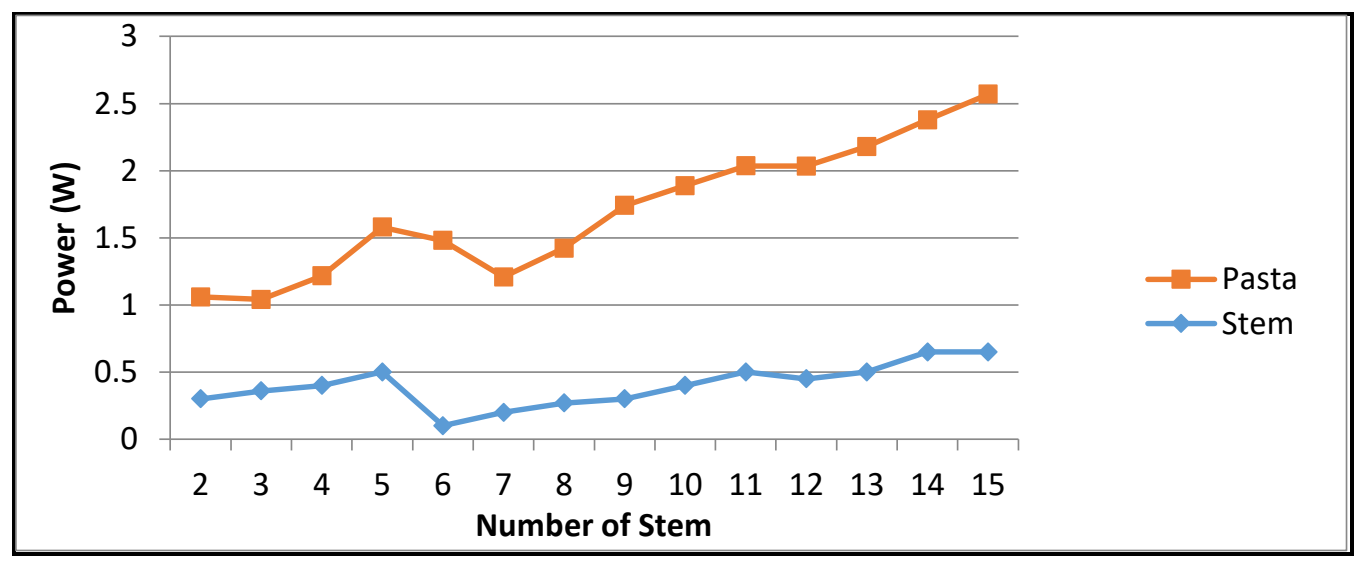

Figure 12. Graph of the Relationship of Power to the Number of Stem Arranged in Parallel on Pasta and Red Dragon Fruit Stem 
Table 1. Results of Measuring Acidity (pH)

\begin{tabular}{cc}
\hline Test Type & $\mathrm{pH}$ Indicator \\
\hline Red Dragon Fruit Stem & 5 \\
Red Dragon Fruit Stem Pasta & 5 \\
\hline
\end{tabular}

Figure 11 shows the relationship of stress to variations in the number of stem arranged in parallel from pasta and red dragon fruit stem. The resulting stress on the dragon fruit stem pasta is greater than that of the dragon fruit stem. The graph above shows the relationship between the voltage and the number of stem arranged in parallel originating from pasta and red dragon fruit stem is almost constant, because if we arrange several DC voltage sources in parallel, the amount of voltage generated is constant.

Figure 12 shows the power relationship to the parallel-assembled stem of pasta and red dragon fruit stem. Seen in the power's graph relationship produced by each sample, the more variations in the number of power bars produced by each sample increases. This is because power results from the formula $\mathrm{P}=\mathrm{V} x \mathrm{I}$, meaning that if the voltage and current obtained are large, the power generated is also large, otherwise if the voltage and current obtained are small, the power generated is also small.

\section{Degree of Acidity (pH)}

According to (Hendri, Yasni, 2015), acidity of a material can affect its electrical conductivity. The more acidic the electrolyte solution, the higher the hydrogen ion concentration and the greater the current flow from the anode to the cathode. A battery is a device that can produce electrical energy because it consists of two electrodes and an acidic electrolyte solution. We relate the acidity of a substance to fermentation. According to (Yasa. W. K., 2019) Fermentation is a process that produces energy in cells in the absence of oxygen (anaerobic). In general, we carry fermentation out to produce acidity from the material, after completing the process, acidity can be determined using a $\mathrm{pH}$ meter.

Materials that have a strong acidity produce a small $\mathrm{pH}$ value and materials that have a weak acidity produce a large $\mathrm{pH}$ value. A material is acidic if the $\mathrm{pH}$ value is $<7$. The smaller the $\mathrm{pH}$ value, the greater the electrical conductivity of the solution and vice versa, the greater the $\mathrm{pH}$ value, the smaller the electrical conductivity of the solution.

From Table 1, we can see that the degree of acidity $(\mathrm{pH})$ measured using a $\mathrm{pH}$ indicator has the same result $=5$ for both pasta and red dragon fruit stem.

\section{CONCLUSION}

From the results of the research and discussion, we can conclude that: Red dragon fruit stem (Hylocereus polyrhizus) can produce electrical energy both for stem and pasta (mashed), the electrical energy produced is different when tested with various variations. However, the value of the degree of acidity $(\mathrm{pH})$ between the stem and the red dragon fruit stem pasta is the same, namely $\mathrm{pH}=5$.

The results of the study for 5 red dragon fruit sticks, which were arranged in series using time variations (current $0.1 \mathrm{~mA}$; voltage $2.8 \mathrm{~V}$ ) while the results of the study for 5 red dragon fruit sticks arranged in series using time variations (current $0.05 \mathrm{~mA}$; voltage $2.8 \mathrm{~V}$ )

The results of the study were 15 red dragon fruit stem pastas arranged in series with variations in the number of stem (current $2 \mathrm{~mA}$; voltage $1 \mathrm{~V}$ ) while the results of the study were 15 red dragon fruit stem arranged in parallel to variations in the number of stem (current 0.65 $\mathrm{mA}$; voltage $1 \mathrm{~V}$ ).

Acidity $(\mathrm{pH})$ produced by the pasta and red dragon fruit stem when measured with a $\mathrm{pH}$ indicator, namely getting a $\mathrm{pH}$ value $=5$.

Based on the results of the research presented, we can also use the red dragon fruit stem as a new innovation in renewable energy in the electricity sector.

\section{REFERENCES}

Ahmad Wahid, dkk. (2014). Analisis Kapasitas Dan Kebutuhan Daya Listrik Untuk Menghemat Penggunaan Energi Listrik Di Fakultas Teknik Universitas Tanjungpura. 
Jurnal Teknik Elektro UNTAN, 2(1), 10.

Dinata, I., \& Sunanda, W. (2015). Implementasi Wireless Monitoring. Nasional Teknik Elektro, 1, 83-88.

Haluan harian.com. (2018). Petani Buah Naga Melawan Wabah. https://www.harianhaluan.com/news/detail /72372/petani-buah-naga-melawan-wabah.

Hendri, Yasni, G. dan R. (2015). Pengaruh Jenis Kulit Pisang dan Variasi Waktu Fermentasi Terhadap Kelistrikan dari Sel Accu dengan Menggunakan Larutan Kulit Pisang. Pillar of Physic, 6, 97-104.

Hendri, N. Y., Gusnedi, \& Ratnawulan. (2015). Pengaruh Jenis Kulit Pisang dan Variasi Waktu Fermentasi Terhadap Kelistrikan dari Sel Accu dengan Menggunakan Larutan Kulit Pisang. Pillar of Physic, 6, 97-104.

Idawati, N. (2013). Budidaya Buah Naga.

Ilham Noor, Muhammad, Yufita, Zulfalina. (2016). Identifikasi Kandungan Kulit Buah Naga Merah Menggunakan Fourier Transform Infrared (FTIR) dan Fitokimia. Journal of Aceh Physics Society., 5(1), 14.

Imama. A. R. (2015). Energi, Arus dan Tegangan Listrik Bahan Elektrolit Berbentuk Agar-agar dari Limbah Buah dan Sayuran.

Irsan, Supriyanto, A., \& Surtono, A. (2015). Analisis Karakteristik Elektrik Limbah Kulit Singkong (Manihot esculenta Crantz) sebagai Sumber Energi Listrik Alternatif
Terbarukan untuk Mengisi Baterai Telepon Genggam. Jurnal Teori dan Aplikasi Fisika, II, 9-18.

Kristanto, D. (2003). Buah Naga: Pembudidayaan di Pot dan di Kebun.

Oren, Y. (2008). Capacitive deionization (CDI) for desalination and water treatment past, present and future (a review). Desalination, $228,10-29$.

Panjuantiningrum, F. (2009). Pengaruh Pemberian Buah Naga Merah (Hydrocereus Polyrhizus). Terhadap Kadar Glukosa Darah Tikus Putih yang Diinduksi Aloksan. Skripsi, Universitas Sebelas Maret.

Rajagukguk, Agus, Sofyan, F. (2015). Kajian Perencanaan Kebutuhan dan Pemenuhan Energi Listrik di Kota Manado. . . E-jurnal Teknik Elektro dan Komputer, Manado: Jurusan Teknik Elektro-FT.

Rosman, A. R. E. Y. (2019). Karakteristik Arus dan Tegangan Pada Rangkaian Seri dan Rangkaian Paralel dengen Menggunakan Resistor. Jurnal Ilmiah d'computer, 9.

Tempo.com. (2013). Mahasiswa Ini Bikin Baterai dari Kaktus Centong. https://tekno.tempo.co/read/477869/mahasi swa-ini-bikin-baterai-dari-kaktuscentong/full\&view $=$ ok

Yasa. W. K. (2019). Pemanfaatan berbagai Limbah Buah - Buahan sebagai Sumber Energi Listrik. Jurnal Pendidikan Teknologi Pertanian., 5(2). 